\title{
Why New Zealand Should Introduce Paid "Dad and Partner Leave"
}

\author{
AMANDA REILLY* and SUZY MORRISSEY**
}

\begin{abstract}
Paid parental leave was introduced in New Zealand as a 12-week period in 2002, expanded over a number of years to 16 weeks and, from 1 April 2016, became available for 18 weeks. Debate in New Zealand has focussed on the desirability of further extending the period of leave available and on widening eligibility. This paper, however, makes the case that the introduction of an independent entitlement to a separate period of paid parental leave for fathers/partners should be a priority. It argues that such a measure would further equality between men and women and would bring New Zealand law into line with corresponding policies in other developed economies and with International Labour Organization (ILO) recommendations. This paper also considers the question of the design of such an entitlement. It concludes that partner leave should be well paid, ring fenced for 'dads and partners' (as the equivalent Australian provision is), and at least two weeks long. The options that it could potentially be funded by employers rather than the state, and could be made compulsory, are also discussed.
\end{abstract}

\section{Key words}

Fathers, paid parental leave, gender norms, New Zealand, International Labour Organization.

\section{Introduction}

There is growing recognition of the importance of fathers as caregivers and not just as breadwinners. ${ }^{1}$ However, 49 per cent of fathers in a survey carried out by the Families Commission felt that New Zealand society did not value fathers, ${ }^{2}$ and it is clear that New Zealand lags behind other developed countries in terms of its provision of a period of paid partner leave. Australia, for example, on the recommendation of the Productivity Commission, introduced "Dad and Partner Pay" on 1 January 2013. ${ }^{3}$ This statutory entitlement consists of a 2-week payment at the rate of the national minimum wage for eligible working fathers and partners. The central thesis of this paper is that New Zealand fathers should have a similar independent entitlement to paid parental leave.

\footnotetext{
* Amanda Reilly, Lecturer, School of Accounting and Commercial Law, Victoria University of Wellington

** Suzy Morrissey, PhD student, School of Accounting and Commercial Law, Victoria University of Wellington.

${ }^{1}$ Laura Addati, Naomi Cassirer and Katherine Gilchrist Maternity and paternity at work: Law and practice across the world (ILO, 2014); R Levtov and others State of the World's Fathers (MenCare, 2015).

${ }^{2}$ Francis Luketina, Carl Davidson and Penny Palmer Supporting Kiwi Dads: Role and Needs of New Zealand Fathers (Families Commission, Research Report No 5/09, 2009) at 12.

${ }^{3}$ The Productivity Commission found that a paid parental leave scheme incorporating paid partner leave for fathers and partners would have significant benefits, "including reducing the pressures of caring and working on parents when their children are young, increasing the involvement of fathers in the early months of a child's life, and providing a strong signal that taking time out of the paid workforce to care for a child is viewed by the wider community as part of the usual course of life and work for parents." See Australian Government: Department of Social Services "Paid Parental Leave: Dad and Partner Pay" (2011)<www.dss.gov.au>.
} 
Some qualifications are necessary: although this paper focusses on fathers, there is no reason that paid partner leave should be reserved exclusively for the male partners of biological birth mothers and that is not what is here advocated. Naturally, same sex couples or couples adopting children should be entitled to equal treatment and not subject to discrimination. While this point will not be further addressed, it is acknowledged and it can be easily achieved if the eligibility is framed in the legislation as turning on the status of designated "partner to a primary caregiver". It also must be acknowledged that a nuclear family of two parents and child is not the only possible family configuration, nor is it inherently a superior arrangement more deserving of support. However, a detailed analysis of the ramifications of all possible family structures is beyond the scope of this paper, which is focussed on progressing equality between men and women and proposing a modest incremental improvement on the status quo.

The first part of this paper summarises existing entitlements, including their recent expansion. The second part comprises of an argument that men should be entitled to a separate right to paid parental leave. The third part discusses issues relevant to the possible design of a separate entitlement to paid parental leave for men. It is concluded that shifting entrenched gender norms and practices to improve equality between men and women, both at home and at work, is likely to prove a difficult and lengthy task. Nonetheless, recognition of a separate entitlement to paid leave for 'dads and partners' could prove to be an important first step.

\section{Existing entitlements}

Currently, New Zealand fathers who have been employed continuously for 12 months are entitled to two weeks' unpaid partner leave upon the birth of a child under the Parental Leave and Employment Protection Act 1987. ${ }^{4}$ However, it appears that uptake of this is very low; the most recent data suggests that just four per cent of men exercise the right to take this unpaid leave. ${ }^{5}$ Some men use accumulated annual leave to take some time off around the birth of a child, but not all fathers have the opportunity to do this. ${ }^{6}$

There is some paid leave potentially available. Since 1 July 2002, eligible women and men have been entitled to paid leave from employment upon the birth or adoption of a child under the Parental Leave and Employment Protection Act 1987. ${ }^{7}$ This period of parental leave is theoretically available to either or both parents. This is in keeping with international trends; shared parental leave is normally available for both men and women, and countries which reserve leave exclusively for mothers are rare. ${ }^{8}$ However, in New Zealand, as elsewhere, this theoretically shared leave is largely taken by women and transfers of the paid leave entitlement

\footnotetext{
${ }^{4}$ Part 2.

${ }^{5}$ Paul Callister Parental Leave in New Zealand: 2005 / 2006 Evaluation (Department of Labour, May 2007) at 40. This study found that fathers who took leave chose to take it as annual leave rather than unpaid leave for financial reasons.

${ }^{6}$ More than 40 per cent of fathers in the Families Commission survey reported that they had no opportunity to take leave: see Luketina, Davidson and Palmer, above n 2, at 12, although in the Callister survey only 27 out of 150 fathers took no leave: see Callister, above n 5 .

${ }^{7}$ Parts 1 and 7A. The budgeted amount of paid parental leave in the 2014-2015 financial year was NZD \$176 million: see The Treasury Vote Revenue: The Estimates of Appropriations: Finance and Government Administration Sector (B5 Vol 5, 2014) at 186. For those who are not eligible for paid parental leave, there is an alternative called the Parental Tax Credit (PTC). This short term payment is part of the Working for Families tax package. One-off payments at the birth of a child (often referred to overseas as a 'baby bonus') have not been a feature of the New Zealand welfare system.

${ }^{8}$ Addati, Cassirer and Gilchrist, above n 1, at 62.
} 
to a partner occur in less than one per cent of cases. ${ }^{9}$ It has become apparent that, when parental leave may be taken by either women or men, in practice, it is usually women that take it. ${ }^{10}$ There are a range of reasons for this, but one of the most significant is that recovery from childbirth and breastfeeding are seen as being supported by paid parental leave. ${ }^{11}$ It is, therefore, understandable that, where there is a choice between who takes the leave, women usually take it.

Within New Zealand, proposals for change have focussed on extending the length of the payment period. ${ }^{12}$ Initially set at a period of 12 weeks, it was extended to 13 weeks in 2004. The 2014 Budget amended the Act to extend paid leave to 16 weeks from 1 April 2015, and to 18 weeks from 1 April 2016. Calls to extend it further continue. In 2014, Labour MP Sue Moroney introduced the Parental Leave and Employment Protection (Six Months' Paid Leave) Amendment Bill as a Members Bill and established the ' 26 for Babies' coalition to support the cause. The Bill was defeated in February 2015 but, in a surprise outcome, was redrawn in the Ballot and went through the parliamentary process again. ${ }^{13}$ This Bill aimed to extend paid parental leave to 26 weeks from 1 April 2018, but was vetoed by the National Government at its third reading on 29 June 2016.

The Parental Leave and Employment Protection Amendment Act 2016, which came into force on 1 April 2016, widened eligibility for paid leave to a larger group of workers. Prior to this, a mother was eligible for paid parental leave if she had worked for the same employer for either six or 12 months before the due date. Additionally, she must have worked an average of at least 10 hours a week, including at least one hour every week or 40 hours in every month before the expected date of delivery of the child. Effectively, paid parental leave was targeted towards those with stable, regular employment patterns. The new legislation, however, extends the eligibility for payment to "primary carers" who have been employed by the same employer for at least an average of 10 hours per week over any 26 of the 52 weeks immediately preceding the date of the delivery of the child. ${ }^{14}$ This means that workers previously excluded from the entitlement due to an inability to meet the continuity of employment requirements will be better off.

As the previous legislation did, the new law provides that a portion or the entirety of the paid leave may be transferred to partners or to other caregivers. ${ }^{15}$ However, it remains very much targeted at mothers. A primary carer is defined as the biological mother of the child, ${ }^{16}$ or "the spouse or partner of the biological mother" if that person has succeeded to, or received transfer of, the biological mother's parental leave payment entitlements. ${ }^{17}$ Hence, the change does not provide any additional incentive or reason for a portion of this leave to be transferred to a partner than the previous legislation did. There is, therefore, no reason to expect any increase in the occurrence of men and women sharing leave.

\footnotetext{
${ }^{9}$ Ministry of Business, Innovation and Employment Regulatory Impact Statement: Modernising Parental Leave (2015) at 4.

${ }^{10}$ Addati, Cassirer and Gilchrist, above n 1, at 65.

${ }^{11}$ Callister, above $\mathrm{n} 5$.

${ }^{12}$ See Paul Callister and Judith Galtry “'Baby Bonus’ or Paid Parental Leave - which one is better?” (2009) 34

Social Policy Journal of New Zealand 1, advocating for an extension to six months to support breastfeeding.

13 Parental Leave and Employment Protection (Six Months' Paid Leave and Work Contact Hours) Amendment

Bill 2016 (51-2).

${ }^{14}$ Section $2 \mathrm{BA}(4)$.

${ }^{15}$ Sections 7(1)(c) (other caregivers) and 71E (spouses or partners).

${ }^{16}$ Section 7(1)(a).

${ }^{17}$ Section 7(1)(b).
} 
Recent changes, including the introduction of a longer period of paid leave and the extension of eligibility to a wider range of workers, are commendable in that they will assist families during a financially challenging time. However, the next section argues that, if equality between men and women is to be served, a separate period of paid leave for fathers/partners should be a priority in the future, rather than further extension of the existing paid parental leave entitlement.

\section{Why fathers/-partners should have a separate entitlement to paid parental leave}

\section{Equality between men and women}

It is uncontroversial to note that the position of women in the workforce is unequal to that of men. This is demonstrated by the gender pay gap and the dominance of men in senior roles in almost all sectors. While the reasons for women's continuing disadvantage in the workplace are complex, according to Holmstrom and others "[w]hat helps maintain this situation of unequal pay for equal work... for women, is their role in the family". ${ }^{18}$ This is borne out by the New Zealand Time Use Survey, which indicates that men and women spend a similar amount of time on paid and unpaid work activities combined, but most male work is paid (63 per cent) and most female work is unpaid (65 per cent). ${ }^{19}$

Improving equality for women in the workplace requires addressing men's inequality in the home. Young suggests that "the sharing of child care responsibilities by women and their male partners is an essential step in women's struggle for equality." ${ }^{20}$ Gornick and others note "the potential costs of increasing and strengthening women's labour-market ties - without achieving gender parity in unpaid work". ${ }^{21}$ The risk is that women will have to spend more time on paid work without any reduction in their unpaid workload - in effect, they will be required to work a Second Shift ${ }^{22}$ at home upon completing their day's work. Also, as long as women carry a greater burden of caring work in the home, they will be unable to compete with men on equal terms in the workplace and workplaces will continue to be structured around the norm of an ideal worker who has no care responsibilities. ${ }^{23}$

Increased shared parenting will not only benefit women by improving their ability to participate in the paid workforce. Okin argues for "shared child rearing for justice between the sexes", 24 and there are emotional benefits to men in having greater involvement with their children. Notwithstanding these benefits, Cunningham-Parmeter summarises core insights drawn from the emergent field of masculinities theory which clarify some of the barriers to men's

\footnotetext{
${ }^{18}$ Nancy Holmstrom “Women's Work: the Family and Capitalism” (1981) 45(2) Science \& Society 186 at 197.

${ }^{19}$ Statistics New Zealand Time Use Survey: $2009 / 2010$ (21 June 2011) at 1.

${ }^{20}$ Claire Young “Child Care - A Taxing Issue?” (1994) 39 McGill LJ 539 at 550.

${ }^{21}$ Janet Gornick "Gender Equality in the Labour Market" in Diane Sainsbury (ed) Gender and Welfare State Regimes (Oxford University Press, Oxford, 1999) 210 at 213. See also Nancy Fraser "After the Family Wage: What Do Women Want in Social Welfare?” (1994) 21(1) Social Justice 80.

${ }^{22}$ The concept of the second shift was first articulated by Arlie Hochschild: see Arlie Hochschild and Anne Machung The Second Shift: Working Parents and the Revolution at Home (Avon Books, New York, 1990).

${ }^{23}$ Joan Williams Unbending Gender: Why Family and Work Conflict And What To Do About It (Oxford University Press, New York, 2000).

${ }^{24}$ Susan Okin Justice, Gender and the Family (Basic Books, New York, 1989) at 116.
} 
engagement in caregiving. ${ }^{25}$ This theory posits that gender is socially constructed and that hegemonic masculinity requires men to prove that they are not like women or non-dominant men. As carework, dependency and emotiveness are associated with women, masculine identity requires fathers to be stoic providers and breadwinners who do not engage in carework. Cunningham-Parmenter notes that few men can satisfy this ideal, yet the breadwinner myth persists and men who do not comply with gender norms and hierarchies face backlash.

It is arguable that new gender norms are emerging to challenge hegemonic masculinity. A number of studies suggest that New Zealand men want to spend more time with their families and to be more involved with the care of their children. ${ }^{26}$ Notably, however, one study suggested that, while 92 per cent of New Zealand parents believe that a father should be as heavily involved in the care of his children as the mother, only 53 per cent report that they do actually share childcare responsibilities. ${ }^{27}$

If women have a right to equal participation in the workplace, the corollary of this is that men must have a right to equal participation in the home: a right to be actively engaged as parents and not just as breadwinners. Equality in this context does not mean that men and women must be viewed and treated as exactly alike in every respect. With very few exceptions, pregnancy is unique to women, ${ }^{28}$ as is breastfeeding, and should be treated as such. This suggests that some accommodation for women around recovery from childbirth and breastfeeding, such as the current availability of a period of leave following childbirth, are necessary. Thereafter, however, parenting is a learned practice ${ }^{29}$ which men and women are equally capable of and, as argued by Fredman, true substantive equality requires "a levelling up option extending women's parenting rights to fathers." 30

\section{Paid partner leave as a first step towards addressing inequality}

No single measure can, by itself, achieve the dual goals of improving women's equality in the workplace and men's equality in the home. However, further extension of the existing right to paid parental leave, which is currently almost exclusively taken by women, runs the risk of being counterproductive in that it may reinforce the gender norm that childcare is the responsibility of women. Also, women who remain out of the workforce for extended periods of time lose seniority and earnings, which is damaging to their long term career prospects. ${ }^{31}$

By contrast, the introduction of a period of paid leave for fathers around the time of birth could encourage men to take on more responsibility in the home. Research suggests that fathers who take leave, especially those taking two weeks or more immediately after childbirth, are more likely to be involved with their young children. ${ }^{32}$ This also empowers fathers as parents, as

\footnotetext{
${ }^{25}$ Keith Cunningham-Parmenter "Men at Work, Fathers at home: Uncovering the Masculine Face of Caregiver Discrimination" (2013) 24(3) Colum J Gender \& L 253.

${ }^{26}$ Luketina, Davidson and Palmer, above $\mathrm{n} 2$.

${ }^{27}$ Callister, above $\mathrm{n} 5$.

${ }^{28}$ Although, note Thomas Beatie as a rare example of a transgender man who underwent pregnancy three times.

${ }^{29}$ Cunningham-Parmenter, above n 25, at 279.

${ }^{30}$ Sandra Fredman "Reversing roles: bringing men into the frame" (2014) 10 Int J Law Context 442.

${ }^{31}$ Discussed in Vanessa Long "Statutory Parental Leave and Pay in the UK: Stereotypes and Discrimination" (2012) 9 Equal Rights Review 52.

${ }^{32}$ Maria Huerta and others Fathers' Leave, Fathers' Involvement and Child Development: Are They Related? Evidence from Four OECD Countries (OECD Social, Employment and Migration Working Papers No 140, 14 January 2013) at 52. See also Linda Haas and Tine Rostgaard "Fathers' rights to paid parental leave in the Nordic countries: consequences for the gendered division of leave" (2011) 14(2) Community Work Fam 177; Linda Haas,
} 
noted by Rehel. ${ }^{33}$ By drawing fathers into the daily realities of childcare, free of workplace constraints, extended time off provides the space necessary for fathers to develop the parenting skills and sense of responsibility that then allows them to be active co-parents, rather than helpers, to their female partners. This shift from a manager-helper dynamic to that of coparenting creates the opportunity for the development of a more gender equitable division of labour.

Evidence suggests that improving men's access to leave has a positive effect on women's workplace participation. It seems that more equitable parental leave policies increase the likelihood that women will return to employment after leave and spend more time in paid work. ${ }^{34}$ One study indicates that "each month the father stays on parental leave has a larger positive effect on maternal earnings than a similar reduction in the mother's own leave." 35

Greater involvement by fathers at an early stage could even have implications for future generations. One study indicates that fathers taking parental leave may correlate to adolescent daughters spending less time on housework. ${ }^{36}$ There are other advantages too, as research indicates that fathers taking leave contributes "positive long-term effects for both father and child", ${ }^{37}$ a reduction in violence towards children and women, ${ }^{38}$ and an improvement in women's post-birth health, including less sickness and depression. ${ }^{39}$

\section{ILO recommendations and international comparisons}

Given the potential for a period of paid paternal leave for men to improve equality, the Human Rights Commission has called for a separate entitlement for men to be introduced. ${ }^{40}$ The Commission has also noted that New Zealand currently compares poorly on an international basis. ${ }^{41}$ It is true that, in only providing two weeks' unpaid leave to fathers, New Zealand is out of sync with other countries. The ILO has indicated that, in the vast majority of countries that provide partner leave, it is paid ( 70 countries out of 78 , or 90 per cent in total). ${ }^{42}$ There are only eight countries where national legislation does not provide for benefits to cover work absences due to partner leave where there is an entitlement to take time off: Azerbaijan, the Bahamas, Ethiopia, Kazakhstan, Republic of Korea, New Zealand, Norway and the Syrian Arab Republic.

and C Philip Hwang "The Impact of Taking Parental Leave on Fathers' Participation in Childcare and Relationships With Children: Lessons from Sweden" (2008) 11(1) Community Work Fam 85. See also Australian Government: Productivity Commission Paid Parental Leave: Support for Parents with Newborn Children (Inquiry Report No 47, 28 February 2009) at 4.52: "evidence suggests that partner leave has emotional benefits for fathers, facilitates bonding between fathers and children, positively affects children's emotional and educational achievements and provides support for the mother."

${ }^{33}$ Erin Rehel "When Dad Stays Home Too" (2014) 28(1) Gender \& Society 110 at 52.

${ }^{34}$ Olivier Thévenon and Anne Solaz Labour Market Effects of Parental Leave Policies in OECD Countries (No 141, OECD Social, Employment and Migration Working Papers, OECD Publishing, 2013) at 8.

${ }^{35}$ Elly-Ann Johansson The effect of own and spousal parental leave on earnings (Institute for Labour Market Policy Evaluation, Working Paper 2010:4) at 4.

36 Andreas Kotsadam and Henning Finseraas "Causal Effects of Parental Leave on Adolescents' Household Work" (2013) 92(1) Soc Forces 329.

${ }^{37}$ Brad Harrington and others The New Dad: Take Your Leave: Perspectives on paternity leave from fathers, leading organizations and global policies (Boston College Center for Work \& Family, 2014) at 2.

${ }^{38}$ Fatherhood Institute Parenting Leave Arrangements: Which 'architecture' is best for young children? (2013) at $7-8$.

${ }^{39}$ Harrington and others, above n 37, at 3.

${ }^{40}$ Human Rights Commission Human Rights in New Zealand 2010 (2010) at 299.

${ }^{41}$ At 299.

${ }^{42}$ Addati, Cassirer and Gilchrist, above n 1, at 57. 
In failing to have a separate paid entitlement for men, New Zealand is not only lagging behind other developed countries, but is implicitly failing to follow ILO recommendations. While some rights set in place by the ILO implicitly reinforce "women's primary responsibility for childcare" 43 and the ILO has not devoted much attention to the role of fathers, the ILO Workers with Family Responsibilities Convention 1981 (No 156) does refer to fathers responsibilities, stating at art 3(1):

...each member shall make it an aim of national policy to enable persons with family responsibilities who are engaged or wish to engage in employment to exercise their right to do so without being subject to discrimination and to the extent possible, without conflict between their employment and family responsibilities.

More recently, the International Labour Conference Resolution concerning gender equality at the heart of decent work called for member states to develop policies "allowing for a better balance of work and family responsibilities for both women and men in order to allow a more equal sharing of these responsibilities." 44

Although paid partner leave in and of itself will not be sufficient to shift entrenched gender norms, it has been suggested that: ${ }^{45}$

Leave measures have transformative potential when the achievement of effective equality at work and in the household are an explicit objective in line with the ILO Workers with Family Responsibilities Convention 1981.

\section{How should paid partners' leave be designed?}

\section{Addressing barriers to uptake}

The previous section argued that paid partner leave is a mechanism that may help to promote gender equality in the labour market and in caregiving, which may also have other advantages. To be effective, such a mechanism must take account of interlocking barriers that might discourage men from taking up an entitlement to leave. These include socialisation and gender norms,${ }^{46}$ financial pressures, ${ }^{47}$ and lack of support from employers. ${ }^{48}$

Incentives to counter gender norm pressures are critical. ${ }^{49}$ The more individual men are encouraged to take leave, the more socially acceptable this becomes. As noted above, where there is a possibility that leave may be shared, it is generally women that take it. For this reason, there has been a movement towards allocating exclusive, non-transferable individual rights to

\footnotetext{
${ }^{43}$ Fredman, above n 30, at 449.

${ }^{44}$ Addati, Cassirer and Gilchrist, above n 1, at 52.

${ }^{45}$ At 52 .

46 SB Burnett and others "Fathers at work: A ghost in the organisational machine" (2013) 20(6) Gender, Work and Organization 632 as cited in Addati, Cassirer and Gilchrist, above n 1, at 52.

47 "After the birth of a child the majority of fathers feel increased pressure as the main income earner and have greater concern about financial security": Callister, above n 5, at 46.

${ }^{48}$ For example, male lawyers who take parental leave are seen as "wimp-like": Okin, above n 24, at 126.

${ }^{49}$ Addati, Cassirer and Gilchrist, above n 1, at 52.
} 
fathers, sometimes known as 'daddy quotas' ${ }^{50}$ on a 'use or lose it' basis. ${ }^{51}$ Evidence suggests that parental leaves which allocate non-transferable portions to the father lead to higher takeup by fathers. ${ }^{52}$ It is notable that "fathers in Denmark stopped taking leave when the quota was removed there". 53

Another option to encourage fathers to take leave is to offer additional leave if both parents take parental leave, and currently eight countries offer such a bonus. ${ }^{54}$ However, it appears that, although fathers may take their 'daddy quota' period of leave, where there is additional leave available to either parent, the "vast majority [of fathers] do not take any of that additional period of leave". ${ }^{55}$ Therefore, this may not be a desirable option in the New Zealand context.

Financial concerns can also operate as a significant impediment to fathers taking leave. Due to the gender pay gap, it is likely that a father would be providing more financial resources to the family. If only unpaid, or poorly paid, leave is available, the father being at home may not be an option, due to the financial stress the loss of the father's income would cause to the family. Currently, in New Zealand, regardless of whether paid parental leave is taken by the father or the mother (assuming both are eligible), the same maximum amount of $\$ 516.85$ per week before tax is payable. As this is significantly below the median weekly income from wages and salaries $(\$ 882)^{56}$ and the minimum wage for a 40 hour week (\$590), families are likely to face financial pressure after a birth. ${ }^{57}$

Accordingly, dedicated partner leave must be paid at a generous rate. Internationally, where partner leave is paid, use of leave entitlements has been shown to be highest when compensation is at least 50 per cent of earnings. ${ }^{58}$ However, it may be seen as discriminatory if parental leave, almost entirely taken by women, is paid at below the minimum wage, while partners' leave, almost entirely taken by men, is paid at a higher rate. In Australia, Dad and Partner Pay is paid at same the rate of the National Minimum Wage (currently around $\$ 590$ a week before tax), which is the same weekly rate as Parental Leave Pay. A single, flat rate that equates to minimum wage would send a signal that parenting by both parents is equally valued, so this may be the best option as a first, modest step.

\footnotetext{
${ }^{50}$ Linda Barclay "Liberal Daddy Quotas: Why Men Should Take Care of the Children and How Liberals Can Get Them to Do It" (2013) 28(1) Hypatia 163 at 164.

${ }^{51}$ Addati, Cassirer and Gilchrist, above n 1, at 62. This is the approach of the European Union under Directive 2010/18/EU on Parental Leave [2010] OJ L68/13.

52 Berit Brandth and Elin Kvande "Flexible work and flexible fathers" (2001) 15(2) Work Employment \& Society 251 as cited in Addati, Cassirer and Gilchrist, above n 1, at 61; M O’Brien "Fathers, parental leave policies, and infant quality of life: International perspectives and policy impact" (2009) 624(1) The ANNALS of the American Academy of Political and Social Science 190 as cited in Addati, Cassirer and Gilchrist, above n 1, at 61; C Rutten "Parental leave in Europe and social [exclusion] of women from the labour market" (postgraduate paper for Inter University Centre, Dubrovnik, 2012) as cited in Addati, Cassirer and Gilchrist, above n 1, at 61.

53 Elizabeth Lindsay "Father's leave still a burning issue" (20 September 2013) News in English <www.newsinenglish.no>.

${ }^{54}$ Peter Moss and Fred Deven "Leave policies in challenging times: reviewing the decade 2004-2014" (2015) 18(2) Community Work Fam 137.

${ }^{55}$ Barclay, above n 50, at 168.

${ }^{56}$ Statistics New Zealand New Zealand Income Survey: June 2015 quarter (2 October 2015) at 1.

${ }^{57}$ In Norway, the same portion of wages are payable as paid leave (either 100 per cent or 80 per cent), whether taken by the father or mother. This ensures any financial stress on the family is minimal and optional, as the shorter period paid at 100 per cent could be chosen.

${ }^{58} \mathrm{M}$ O'Brien "Fathers, parental leave policies, and infant quality of life: International perspectives and policy impact" (2009) 624(1) The ANNALS of the American Academy of Political and Social Science 190 as cited in Addati, Cassirer and Gilchrist, above n 1, at 52.
} 
It also seems that men are more likely to take leave when the duration is at least 14 days. ${ }^{59}$ Two weeks' paid leave would bring New Zealand in line with other developed economies. As mentioned previously, Australia introduced a two week paid partner leave at the beginning of 2013 and, according to the ILO, only five countries among the developed economies (Finland, Iceland, Lithuania, Portugal and Slovenia) provide a partner leave of more than two weeks. ${ }^{60}$ However, consideration could be given to a longer period. The 2006 Department of Labour Survey indicated that, while it is currently not uncommon for men to take two weeks' annual leave around the birth of the baby, for the men in the survey, the ideal length of leave would be four weeks' concurrent leave with the mother. ${ }^{61}$

\section{Who should pay for it?}

Paid parental leave is currently funded by the state and employers are not required to make any contribution towards it. One of the reasons for this was a recognition that it would largely be women who took advantage of the entitlement, and there were fears that requiring an employer contribution could deter employers from hiring women of childbearing age. This logic is, of course, not applicable to men, so this may provide some weight to the suggestion that employers could be compelled to contribute to all or part of the costs of funding paid paternal leave. If New Zealand were to adopt this option, it would be in keeping with developments in other parts of the world. According to the ILO survey, in 45 countries out of 78 ( 58 per cent), the entitlement is paid by the employer. However, payment through social security is the prevalent funding system in developed economies ( 15 out of 24 countries, or 63 per cent) ${ }^{62}$

On the other hand, a case could also be made that differential funding regimes for men and women are inequitable in that they suggest the state values the care that women provide more than that which men provide.

Legislation is, of course, not the only mechanism to confer an independent entitlement to paid leave upon men. In a number of countries, partner leave is provided through collective bargaining agreements instead of through legislative provisions. ${ }^{63}$ For example, in Norway, the majority of men receive reimbursement during the two weeks of partner leave as part of a collective agreement between the social partners. ${ }^{64}$ While it is not possible to say how many men in New Zealand may receive a separate entitlement to paid parental leave through individual employment agreements, data exists on collective employment agreements. Of these, only three per cent of collective agreements in New Zealand contain a period of separate paid leave for a spouse/partner upon the birth of their child. ${ }^{65}$ Although there is scope for an increase in paid paternal entitlements in collective employment agreements, if unions and employers agree to this, the low and declining coverage of collective bargaining (15.7 per cent of the employed labour force, mostly in the central government sector ${ }^{66}$ makes reliance on universal union-negotiated provision of Dad and Partner paid leave unfeasible.

\footnotetext{
${ }^{59}$ Addati, Cassirer and Gilchrist, above n 1, at 61.

${ }^{60}$ At 53

${ }^{61}$ Callister, above n 5, at 41.

${ }^{62}$ Addati, Cassirer and Gilchrist, above n 1, at 57.

63 At 58

${ }^{64}$ Berit Brandth and Elin Kvande "Norway country note" in Peter Moss (ed) International Review of Leave Policies and Research 2013 (International Network on Leave Policies and Research, June 2014).

${ }^{65}$ Stephen Blumenfeld, Susan Ryall and Peter Kiely Employment Agreements: Bargaining Trends \& Employment Law Update 2014 / 2015 (Victoria University of Wellington Centre for Labour, Employment and Work, 2015).

${ }^{66}$ Blumenfeld, Ryall and Kiely, above n 65.
} 


\section{Should it be compulsory?}

It is arguable that paternal leave should be compulsory. Due to social conditioning and gender norms, as noted by Fredman, "fathers are subject to as much or more pressure than mothers to forego any rights to leave which are offered to them." ${ }^{, 67}$ Fredman notes that this issue was considered by the European Parliament, and the following argument was made: ${ }^{68}$

Partner leave should be established on a binding basis so as to ensure that men will not be made on account of social pressure to forgo their entitlement. A signal should be sent to the labour market to the effect that men too have to spend time away from the workplace and their job when they have children.

This proposal was ultimately rejected by the Council of Ministers. ${ }^{69}$ However, in some countries, a separate period of paternal leave is compulsory in the first month of the birth, for example, in Chile a five day period is compulsory, in Portugal there are 10 days of compulsory leave, and in Italy (on a trial basis) a period of one day was made compulsory. ${ }^{70}$

If this leave was unpaid, it would likely cause financial hardship for families. However, providing that it was paid, making the leave compulsory would send a strong signal about the value that is placed on fathers' involvement with the care of their children. To make all or some paternal leave compulsory might be a step too far for New Zealand, as it could be seen as overly aggressive social engineering that does not sufficiently respect individual choice. Nonetheless, it is worth noting that this exists as an option.

\section{Conclusion}

Shifting entrenched gender norms and practices to improve equality between men and women, both at home and at work is likely to prove a difficult and lengthy task. The present focus on continuing to extend the existing paid parental leave entitlement, which, thus far, has almost exclusively been taken by women, runs the risk of entrenching a gender norm of women as primary caregivers for extended periods, with consequent related disadvantages in the workforce. Recognition of a separate entitlement to paid leave for men may prove to be a feasible step towards more equal outcomes for both men and women at home and at work. At the very least, it would provide a public affirmation that New Zealand society values the care work of fathers.

\footnotetext{
${ }^{67}$ Fredman, above n 30, at 451.

${ }^{68}$ European Parliament Committee on Women's Rights and Gender Equality Report on the Proposal for a Directive of the European Parliament and of the Council Amending Council Directive 92/85/EEC on the Introduction of Measures to Encourage Improvements in the Safety and Health at Work of Pregnant Workers and Workers Who Have Recently Given Birth or Are Breastfeeding (2009) at 14 as cited in Fredman, above n 30, at 451.

${ }^{69}$ Fredman, above n 30, at 451.

${ }^{70}$ Addati, Cassirer and Gilchrist, above n 1, at 56.
} 